IJAMSR 2 (1) www.ijamsr.com CrossRef: https://doi.org/10.31426/ijamsr.2019.2.1.1111

\title{
Professional Commitment and Attitude towards Teaching of Effective Secondary School Teachers
}

\author{
Dr. Rayees Ahmad Dar \\ Faculty of Education, University of Kashmir, Kashmir, India \\ Email: Rayees78601@gmail.com
}

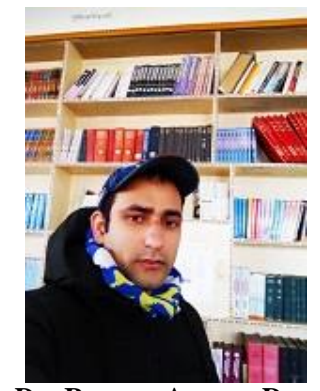

DR. RAYEES AHMAD DAR

Keywords: Attitude towards teaching, Effective and less effective teachers, professional commitment.

\begin{abstract}
A B S T R A C T
This study examined the Attitude towards Teaching of effective and less effective secondary school teachers in Kashmir valley. The sample of the study consisted of 800 secondary school teachers which were collected by random sampling. Attitude towards teaching scale developed by using S.P. Alullwalia's was used. . Professional commitment scale developed by Ravinder Kaur and Sarbjit Kaur was used. The results of the study revealed that the effective secondary school teachers have a favorable attitude towards teaching as compared to less effective secondary school teachers. The results also revealed that effective teachers are more competent in their jobs and also show a positive attitude and are more cooperative to the students and heads of institutions.
\end{abstract}

Citation: Rayees Ahmad Dar (2019).Professional Commitment and Attitude Towards Teaching of Effective Secondary School Teachers. International Journal of Advanced Multidisciplinary Scientific Research (IJAMSR ) ISSN:2581-4281, 2 (1), January, 2019, \# Art.1111, pp 1-9

\section{Introduction}

Education in the largest sense is an act or an experience that has a formative effect on the mind, character or physical ability of an individual. In its technical sense, education is the process by which society deliberately transmits its accumulated knowledge, skills and values from one generation to another society. Education in real sense is to humanize humanity and to make life progressive cultured and civilized. It is very important for the progress of the individual and society. It is through education that man develops his thinking and reasoning, problem solving, intelligence and creativity and aptitude, positive sentiments and skills, good values and attitudes. Education is a dialogue between the past, present and the future, so that the coming generations receive the accumulated lessons of the heritage and carry it forward (UNESCO, 1998). 
Attitude means the individual's prevailing tendency to respond favorably or unfavorably to an object, person or group of people, institutions or events. Attitude can be positive (values) or negative (prejudice). The attitude has been defined in many different ways over the years. The attitude of the teacher has an impact on the behavior of the student in the classroom as well. The teacher spends most of the school day in the close association with his students and as a result of this; his basic attitudes and actions, his tastes and mannerism have great influence on the students. The teachers create the emotional climate in the classroom just by being friendly calm or nervous. This directly affects the children because children learn attitudes and behavior mostly by example. The effectiveness of education depends upon the quality of teachers working in an institution. The quality of teachers in turn depends upon the quality of training received by them in different training institutions. The teacher spends most of the school day in close associations with his students and as a result of this, his basic attitudes and actions, his tastes and mannerism have great influence on the students, the teacher creates the emotional climate in the classroom just by being friendly, calm and nervous. This directly affects the children because children learn attitudes and behavior mostly by examples, emotion, tension, For example, is contagious; a teacher who is fear full and generally hostile can induce fear, worry, and insecurity in his students. The effectiveness of teacher, mainly depends upon the character, ability and his attitude towards his profession teaching. It is true that the attitude of a person towards his profession plays an important role in achieving desirable success. The attitude of a person depends upon his emotions and feelings. Renu and Nand, ( 1999) conducted a study on the attitude of effective teachers towards teaching profession .The main findings of her study were the effective teachers possess better teaching skills than less effective teachers. Their academic scores are high. They are more cooperative with students (Panday, $\mathrm{R}$ and Tripathy, 2006) conducted a study on the attitude of efficient school teachers. The findings indicate that there are good results of education by effective teachers. They have direct influence on the personality of students. The effectiveness of education depends upon quality teachers working in institutions. The quality of teachers in turn depends upon the quality of training received by them in different training institutions. As we know that qualitative and quantitative improvements of elementary and secondary educations has raised problems of solutions of right type of teachers and enriching program of teacher preparation. Thus necessities, but also to inculcate in them desirable teacher like qualities. We know the teaching profession is one of the most important art of guiding students through a variety of methodologies selected teaching methods, and it should therefore, attract the brightest minds, finest personality and most commitment young people as a profession, it requires people who have the right type of attitude for teaching is bound to be a successful teacher in future. A professionally committed teacher educator should possess all the attributes of a professional teacher. As a profession, teaching has been considered as the noblest profession from times immemorial. In this regard the National Policy on Education (1986) has also observed that the status of the teacher reflects the social cultural ethos of a society. Besides, Kothari Commission (19641966) has put forth that of all the different factors which influences the quality, competence and character of teacher are undoubtedly, the most significant 
IJAMSR 2 (1) www.ijamsr.com CrossRef: https://doi.org/10.31426/ijamsr.2019.2.1.1111

\section{International Journal of}

I J A M S R

\section{Advanced Multidisciplinary Scientific Research (IJAMSR) ISSN:2581-4281}

Objectives:

a) To study and compare effective and less effective secondary school teachers on various factors of the Attitude towards teaching.

b) To study and compare effective and less effective secondary school teachers on professional commitment.

\section{Hypotheses:}

a) Effective and less effective secondary school teachers differ significantly on various factors of Attitude towards teaching.

b) Effective and less effective secondary school teachers differ significantly on professional commitment.

\section{Sample:}

The present study was conducted on 800 secondary school teachers from Kashmir valley (400 male and 400 female). The sample was taken randomly from various higher secondary schools in Kashmir division. After that the investigator employed the Teacher Effectiveness Scale by Umme Kulsum for identifying the effective and less effective secondary school teachers. The upper $27 \%$ of sample as effective and lower $27 \%$ of the sample as less effective teachers.

A tool used: The data collected with the help of Job Satisfaction Scale developed by S. P. Alullwalia The inventory was administered to the sample subjects in the respective institutions in order to collect the data. The data was collected with the help of professional commitment scale developed by Ravinder Kaur and Sarbjit Kaur (2011). The inventory was administered to the sample subjects in the respective institutions in order to collect the data.

\section{Statistical Treatment:}

The data was analyzed by applying Mean .S.D and't' test of significance.

\section{Statistical Analysis}

Table 1: Showing the Mean and SD comparison between Effective and Less Effective Secondary School Teachers on their various dimensions of Attitude towards Teaching

\begin{tabular}{|c|c|c|c|c|c|c|}
\hline $\begin{array}{l}\text { Area/Dimensi } \\
\text { ons }\end{array}$ & $\begin{array}{l}\text { Grou } \\
\text { p }\end{array}$ & $\mathbf{N}$ & $\begin{array}{l}\text { Mea } \\
\text { n }\end{array}$ & \begin{tabular}{|l|} 
Std. \\
Deviati \\
on
\end{tabular} & \begin{tabular}{|l} 
t- \\
valu \\
$\mathrm{e}$
\end{tabular} & $\begin{array}{l}\text { Level of } \\
\text { Significa } \\
\text { nce }\end{array}$ \\
\hline \multirow{2}{*}{$\begin{array}{l}\text { Teaching } \\
\text { Profession } \\
(\mathrm{TP})\end{array}$} & $\begin{array}{l}\text { ESS } \\
\mathrm{T}\end{array}$ & $\begin{array}{l}21 \\
6\end{array}$ & $\begin{array}{l}33.3 \\
1\end{array}$ & 6.942 & \multirow{2}{*}{$\begin{array}{l}5.15 \\
9\end{array}$} & \multirow[t]{2}{*}{$\begin{array}{l}\text { Significan } \\
\mathrm{t} \text { at } 0.01 \\
\text { level }\end{array}$} \\
\hline & $\begin{array}{l}\text { LES } \\
\text { ST }\end{array}$ & $\begin{array}{l}21 \\
6\end{array}$ & $\begin{array}{l}27.9 \\
6\end{array}$ & 8.223 & & \\
\hline \multirow{2}{*}{$\begin{array}{l}\text { Classroom } \\
\text { Teaching } \\
(\mathrm{CT})\end{array}$} & $\begin{array}{l}\text { ESS } \\
\mathrm{T}\end{array}$ & $\begin{array}{l}21 \\
6\end{array}$ & $\begin{array}{l}32.8 \\
7\end{array}$ & 6.404 & \multirow{2}{*}{$\begin{array}{l}6.18 \\
2\end{array}$} & \multirow[t]{2}{*}{$\begin{array}{l}\text { Significan } \\
\mathrm{t} \text { at } 0.01 \\
\text { level }\end{array}$} \\
\hline & $\begin{array}{l}\text { LES } \\
\text { ST }\end{array}$ & $\begin{array}{l}21 \\
6\end{array}$ & $\begin{array}{l}26.6 \\
7\end{array}$ & 8.350 & & \\
\hline \multirow{2}{*}{$\begin{array}{l}\text { Child } \\
\text { Centered } \\
\text { Practices }(\mathrm{CC} \\
\text { P) }\end{array}$} & $\begin{array}{l}\text { ESS } \\
\mathrm{T}\end{array}$ & $\begin{array}{l}21 \\
6\end{array}$ & $\begin{array}{l}32.7 \\
8\end{array}$ & 7.218 & \multirow{2}{*}{$\begin{array}{l}6.02 \\
9\end{array}$} & \multirow[t]{2}{*}{$\begin{array}{l}\text { Significan } \\
\mathrm{t} \text { at } 0.01 \\
\text { level }\end{array}$} \\
\hline & $\begin{array}{l}\text { LES } \\
\text { ST }\end{array}$ & $\begin{array}{l}21 \\
6\end{array}$ & $\begin{array}{l}26.6 \\
7\end{array}$ & 7.672 & & \\
\hline
\end{tabular}


IJAMSR 2 (1) www.ijamsr.com CrossRef: https://doi.org/10.31426/ijamsr.2019.2.1.1111

\section{International Journal of}

I J A M S R

Advanced Multidisciplinary Scientific Research (IJAMSR) ISSN:2581-4281

\begin{tabular}{|c|c|c|c|c|c|c|}
\hline \multirow{2}{*}{$\begin{array}{l}\text { Educational } \\
\text { Process (EP) }\end{array}$} & $\begin{array}{l}\text { ESS } \\
\mathrm{T}\end{array}$ & $\begin{array}{l}21 \\
6\end{array}$ & $\begin{array}{l}33.6 \\
9\end{array}$ & 6.689 & \multirow{2}{*}{$\begin{array}{l}7.01 \\
6\end{array}$} & \multirow[t]{2}{*}{$\begin{array}{l}\text { Significan } \\
\mathrm{t} \text { at } 0.01 \\
\text { level }\end{array}$} \\
\hline & $\begin{array}{l}\text { LES } \\
\text { ST }\end{array}$ & $\begin{array}{l}21 \\
6\end{array}$ & $\begin{array}{l}27.0 \\
6\end{array}$ & 7.189 & & \\
\hline \multirow{2}{*}{ Pupils (P) } & $\begin{array}{l}\text { ESS } \\
\mathrm{T}\end{array}$ & $\begin{array}{l}21 \\
6\end{array}$ & $\begin{array}{l}34.2 \\
4\end{array}$ & 6.924 & \multirow{2}{*}{$\begin{array}{l}9.10 \\
1\end{array}$} & \multirow[t]{2}{*}{$\begin{array}{l}\text { Significan } \\
\mathrm{t} \text { at } 0.01 \\
\text { level }\end{array}$} \\
\hline & $\begin{array}{l}\text { LES } \\
\text { ST }\end{array}$ & $\begin{array}{l}21 \\
6\end{array}$ & $\begin{array}{l}25.7 \\
9\end{array}$ & 6.726 & & \\
\hline \multirow{2}{*}{ Teachers $(\mathrm{T})$} & $\begin{array}{l}\text { ESS } \\
\mathrm{T}\end{array}$ & $\begin{array}{l}21 \\
6\end{array}$ & $\begin{array}{l}33.4 \\
7\end{array}$ & 6.755 & \multirow{2}{*}{$\begin{array}{l}5.77 \\
8\end{array}$} & \multirow[t]{2}{*}{$\begin{array}{l}\text { Significan } \\
\mathrm{t} \text { at } 0.01 \\
\text { level }\end{array}$} \\
\hline & $\begin{array}{l}\text { LES } \\
\text { ST }\end{array}$ & $\begin{array}{l}21 \\
6\end{array}$ & $\begin{array}{l}26.5 \\
2\end{array}$ & 10.526 & & \\
\hline \multirow{2}{*}{$\begin{array}{l}\text { Overall } \\
\text { Attitude } \\
\text { towards } \\
\text { Teaching }\end{array}$} & $\begin{array}{l}\text { ESS } \\
\mathrm{T}\end{array}$ & $\begin{array}{l}21 \\
6\end{array}$ & $\begin{array}{l}200 . \\
36\end{array}$ & 23.331 & \multirow{2}{*}{$\begin{array}{l}11.3 \\
04\end{array}$} & \multirow[t]{2}{*}{$\begin{array}{l}\text { Significan } \\
\mathrm{t} \text { at } 0.01 \\
\text { level }\end{array}$} \\
\hline & $\begin{array}{l}\text { LES } \\
\text { ST }\end{array}$ & $\begin{array}{l}21 \\
6\end{array}$ & $\begin{array}{l}160 . \\
61\end{array}$ & 28.128 & & \\
\hline
\end{tabular}

LESST $=$ Less Effective Secondary School Teachers, ETSST $=$ Effective Secondary School Teachers.

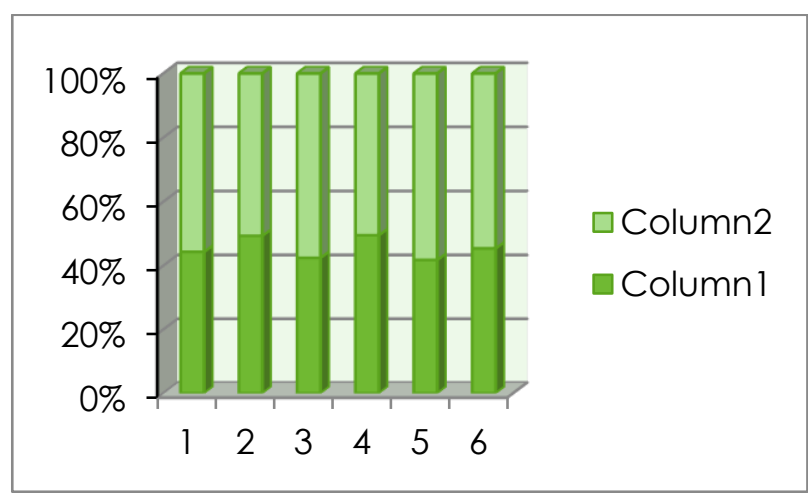

FIG.1: Showing the mean comprising of effective and less effective secondary school teachers on Attitude towards Teaching.
Table 1: Showing the Mean and SD comparison between Effective and Less Effective Secondary School Teachers on their various dimensions of professional commitment.

\begin{tabular}{|c|c|c|c|c|c|c|}
\hline $\begin{array}{l}\text { Area/Dimensio } \\
\text { ns }\end{array}$ & $\begin{array}{l}\text { Grou } \\
\text { p }\end{array}$ & $\mathbf{N}$ & Mean & $\begin{array}{l}\text { Std. } \\
\text { Deviatio } \\
\text { n }\end{array}$ & $\begin{array}{l}t- \\
\text { valu } \\
\text { e }\end{array}$ & $\begin{array}{l}\text { Level of } \\
\text { Significan } \\
\text { ce }\end{array}$ \\
\hline \multirow{2}{*}{$\begin{array}{l}\text { Commitment } \\
\text { to learner }\end{array}$} & ESST & $\begin{array}{l}21 \\
6\end{array}$ & 33.22 & 3.502 & \multirow{2}{*}{$\begin{array}{l}4.36 \\
7\end{array}$} & \multirow{2}{*}{$\begin{array}{l}\text { Significant } \\
\text { at } 0.01 \\
\text { level }\end{array}$} \\
\hline & $\begin{array}{l}\text { LESS } \\
\mathrm{T}\end{array}$ & $\begin{array}{l}21 \\
6\end{array}$ & 31.41 & 5.004 & & \\
\hline \multirow{2}{*}{$\begin{array}{l}\text { Commitment } \\
\text { to society }\end{array}$} & ESST & $\begin{array}{l}21 \\
6\end{array}$ & 32.89 & 3.542 & \multirow{2}{*}{$\begin{array}{l}6.15 \\
4\end{array}$} & \multirow{2}{*}{\begin{tabular}{l}
\multicolumn{2}{l}{ Significant } \\
at 0.01 \\
level
\end{tabular}} \\
\hline & $\begin{array}{l}\text { LESS } \\
\mathrm{T}\end{array}$ & $\begin{array}{l}21 \\
6\end{array}$ & 30.48 & 4.529 & & \\
\hline \multirow{2}{*}{$\begin{array}{l}\text { Commitment } \\
\text { to profession }\end{array}$} & ESST & $\begin{array}{l}21 \\
6\end{array}$ & 34.28 & 4.805 & \multirow{2}{*}{$\begin{array}{l}6.77 \\
4\end{array}$} & \multirow{2}{*}{\begin{tabular}{|lr}
\multicolumn{2}{l}{ Significant } \\
at & 0.01 \\
level &
\end{tabular}} \\
\hline & $\begin{array}{l}\text { LESS } \\
\mathrm{T}\end{array}$ & $\begin{array}{l}21 \\
6\end{array}$ & 31.13 & 4.855 & & \\
\hline \multirow{2}{*}{$\begin{array}{l}\text { Commitment } \\
\text { to attain } \\
\text { excellence }\end{array}$} & ESST & $\begin{array}{l}21 \\
6\end{array}$ & 32.76 & 5.140 & \multirow{2}{*}{$\begin{array}{l}2.68 \\
7\end{array}$} & \multirow{2}{*}{\begin{tabular}{|lr}
\multicolumn{2}{l}{ Significant } \\
at & 0.01 \\
level &
\end{tabular}} \\
\hline & $\begin{array}{l}\text { LESS } \\
\mathrm{T}\end{array}$ & $\begin{array}{l}21 \\
6\end{array}$ & 31.29 & 6.198 & & \\
\hline \multirow{2}{*}{$\begin{array}{l}\text { Commitment } \\
\text { to basic } \\
\text { human values }\end{array}$} & ESST & $\begin{array}{l}21 \\
6\end{array}$ & 32.34 & 4.952 & \multirow{2}{*}{$\begin{array}{l}2.20 \\
8\end{array}$} & $\begin{array}{l}\text { Significant } \\
\text { at } \quad 0.01\end{array}$ \\
\hline & $\begin{array}{l}\text { LESS } \\
\mathrm{T}\end{array}$ & $\begin{array}{l}21 \\
6\end{array}$ & 31.26 & 4.260 & & level \\
\hline \multirow{2}{*}{$\begin{array}{l}\text { Overall } \\
\text { professional } \\
\text { commitment }\end{array}$} & ESST & $\begin{array}{l}21 \\
6\end{array}$ & $\begin{array}{l}165.4 \\
9\end{array}$ & 10.881 & \multirow{2}{*}{$\begin{array}{l}7.79 \\
2\end{array}$} & \multirow[t]{2}{*}{$\begin{array}{l}\text { Significant } \\
\text { at } \quad 0.01\end{array}$} \\
\hline & $\begin{array}{l}\text { LESS } \\
\mathrm{T}\end{array}$ & $\begin{array}{l}21 \\
6\end{array}$ & $\begin{array}{l}155.6 \\
7\end{array}$ & 14.998 & & \\
\hline
\end{tabular}




\section{Discussion and Interpretation of Results}

The perusal of the table no 1 shows the significance of the mean difference between the effective and less effective secondary school teachers on the teaching profession dimension of attitude towards teaching. The mean score of effective secondary school teachers is 33.31 and less effective secondary school teachers are 27.96. The table no 1 makes it clear that the obtained ' $t$ ' value on the dimension (teaching profession) is (5.159), which is greater than the table ' $t$ ' value at 0.01 levels.The mean favors effective secondary school teachers. The effective secondary school teachers who have a favorable attitude towards teaching profession keep the students engaged in teaching learning practice. The effective secondary school teachers develop positive attitude among the students. They always try to motivate the students by a desire to learn, rather than by grades or degree requirements. They prepare the material to be taught in a good manner to the students. The effective secondary school teacher's help in organizing the learned material, thus has a good organizing power. The less effective secondary school teachers have an unfavorable attitude towards teaching profession don't keep the students engaged in the teaching learning process. They are reported to have a low motivating power for the students. They don't take interest in preparing the materials in advance. They have a less motivating power.

The table no 1 also shows the significance of the mean difference between the effective and less effective secondary school teachers on classroom teaching dimension of attitude towards teaching. The mean of effective secondary school teachers is 32.87 and less effective secondary school teachers are 26.61. On this factor (class room teaching) the obtained ' $t$ ' value is
(6.182) which is greater than the table ' $t$ ' value at 0.01 levels. The mean favors the effective secondary school teachers which imply that the effective secondary school teachers have better classroom teaching. The effective secondary school teachers are reported to prepare the material well in advance before they go to a classroom. They make their classroom teaching more effective by giving examples to the students. They always use new techniques and skills in the classroom for new innovations. The effective secondary school teachers who have a good attitude towards class room teaching develop innovative ideas and thinking in the students. They use audio- visual aids in the classroom for enhancing the learning process. The less effective secondary school teachers have low attitude towards class room teaching don't prepare the teaching materials in advance. They use fewer examples in the classroom for explaining the concept development. They use less audio - visual aids in the classroom. They are generally less cooperative in the classroom. They have low command of the demonstrated skill of teaching. They use fewer skills in the classroom. The table no 1 shows the significance of mean differences between effective and less effective secondary school teachers on child centered practice dimension of attitude towards teaching. The mean of effective secondary school teachers is (32.78) and less effective secondary school teachers is (26.67). On this factor (child centered practice) the obtained ' $t$ ' value is (6.029) which is greater than the table ' $t$ ' value at 0.01 levels. The mean favors the effective secondary school teachers which implies that the effective secondary school teachers have better child centered practice. The effective secondary school teachers have a good attitude towards child centered practice and makes the child as the center of teaching learning process. They give freedom to the child in the 
classroom in order to develop the proper attitude among them. They give them time for free discussions and group work. They always try to motivate students to learn more and more. They try to develop the creative and reflective thinking in the students. The less effective secondary school teachers have low attitude towards child centered practice take a little bit of interest in the classroom teaching. They give little bit freedom to the child in the classroom. They don't take part in the group discussion in the class. The table no 1 shows the significance of the mean difference between the effective and less effective secondary school teachers on the educational process dimension of attitude towards teaching. The mean of effective secondary school teachers is (33.69) and less effective secondary school teachers (27.06). On this factor (educational process) the obtained ' $t$ ' value is 7.016 which is greater than the table ' $\mathrm{t}$ ' value at 0.01 levels. The mean favors the effective secondary school teachers which imply that the effective secondary school teachers are good in the educational process as compared to less effective secondary school teachers. The effective secondary school teacher has a good attitude towards educational process developed the proper and positive attitude among the students in the classroom. They make the classroom more active and attractive for learning. They try to develop the self discipline among the students. The help in making the students more democratic and sociable to the school. They develop in the students good moral and spiritual values. They make them available for the school activities and sports activities.The less effective secondary school teachers have low attitude towards the educational process, develop a little bit of positive attitude in the students.
The table no 1 shows the significance of the mean difference between the effective and less effective secondary school teachers on the pupils dimension of attitude towards teaching. The mean of effective secondary school teachers is (34.24) and less effective secondary school teachers is 25.79. On this factor (pupils) the obtained ' $t$ ' value is (9.101) which is greater than the table ' $\mathrm{t}$ ' valueat0. 0level. The mean favors the effective secondary school instructors. The effective secondary school teachers who have a good attitude towards the pupils make the child as the center of education. They develop proper and good attitude among the students. They develop the self concept among the students. They make sociable and democratic atmosphere in the school. They help to try developing in the student's reflective and creative thinking. The less effective secondary school teachers have low attitude towards pupils are not affectionate to the students. They don't develop the proper concept of teaching and learning. The table 1 shows the significance of the mean difference between the effective and lee effective secondary school teachers on the teacher's dimension of attitude towards teaching. The mean of effective secondary school teachers is 33.47 and less effective secondary school teachers are 26.52.On this factor (teachers) the obtained ' $t$ ' value is (5.778) which is greater than the table ' $t$ ' value at 0.01 levels. There is a significant difference between the less effective and effective secondary school teachers on teacher dimension of attitude towards teaching. The effective secondary school teachers who have a good attitude towards the teacher are friendly and cooperative with other members of the school. They make group discussion with the other teachers of the school. They remove their teaching difficulties by discussing with other teachers of the school. They always help each 
other for the progress and benefit of the school. They take an interest in the school activities with each other in the school. They help their partner teachers in the school to develop their creative and reflective thinking. They have the qualities like working together or group working in the school.They show sympathy to the other teachers in the school at large.The less effective secondary school teachers who have low attitude towards teachers are not too much friendly with the other teachers in the school. They make a little bit of discussions in the class and in the school as a whole. They don't have a good attitude towards group working and discussion in the school. While analyzing the mean difference between effective and less effective secondary school teachers on factor (Commitment to Learner) dimension of professional commitment, the results show a clear distinction between the two groups. Effective secondary school teachers are higher on commitment to learner factor of professional commitment. Effective secondary school teachers are reported to have a good level of encouraging power to students, favor the discussions among the learners. The effective teachers are reported to develop the confidence among the students. The effective secondary school teachers develop the psychological insights among the students. The effective teachers remain duty bound for all round development of their students, and are reported to give full attention to the students. The less effective secondary school teachers have low professional committed to learning and are less encouraging to the students, don't create a proper confidence among the students. The less effective teachers don't give equal attention to the students, give less attention to the bright students and ignore the students asking questions.
It is apparent from the results that effective and less effective secondary school teachers differ significantly from each other on factor (Commitment to Society) of professional dedication. The results depict that effective secondary school teachers have a high professional commitment to society and contribute to the welfare of the society. The effective teachers contribute to the development and progressive betterment of the society. The effective teachers are professionally committed to their profession and always focus on the individual's growth so that in future they will contribute to the society. Effective teachers are active and always take part in social progress, seminars and workshop. The effective teachers make the students good citizens of the society. The effective teachers remain sensitive to what people think of teachers in the society, don't discriminate the students on the grounds of caste and religion. They are watchful to the happening in their neighborhood and believe that teachers are the agents of social change. The less effective secondary school teachers have low professional commitment to society, not take too much interest in the betterment and progress of the society. Less effective teachers are lazy not taking participation in social activities. Less effective secondary school teachers don't focus on the individual growth, low contributors to the social change and believe that the upliftment of the society is concern of social workers only.

On the comparison between the two groups of factor (Commitment to Profession) dimension of professional commitment, the results justify that effective and less effective secondary school teachers differ significantly. This envisages that effective secondary school teachers have a high professional commitment to profession and always give priority to the student's needs and interests. 
They fulfill the needs of each individual learner by providing a variety of unique teaching methods and techniques. The effective teachers always strive to motivate and engage students in learning. They advocate for their students to ensure that they are getting everything that they need in order to be a successful educated student. The effective teachers are reported to be an active contributor to the process. They give full priority to their teaching profession. The effective teachers feel upset if anyone speaks ills of the teaching profession. They remain fully committed to their profession and are always ready to work on holidays. The less effective secondary school teachers have low professional commitment to profession don't give priority to their students needs and interests. The less effective secondary teachers are not professionally sound, are reported to have low power of motivation. The less effective teachers find the teaching profession as tiresome due to heavy work load. They find more disadvantages in teaching than advantages and don't remain fully committed to their profession. The effective and less effective secondary school teachers differ significantly in factor (Commitment to Attain Excellence) dimension of professional commitment. The results depict that effective secondary school teachers are higher on the mean score than less effective secondary school teachers. The effective secondary teachers attending the seminars and conferences in order to improve the art of teaching and acquire new dimensions of knowledge and experience. They believe that achieving excellence is a journey that never ends. Effective teachers treat teaching as a profession which requires continuous learning. Effective teachers always go through educational journals and magazines to update their knowledge. Effective teachers are in search of new techniques and pedagogical skills to be utilized in teaching learning process. They are always active in their approach and feel that scope of excellence in the field of teaching is vast. The less effective teachers are lacking these above mentioned qualities. While comparing effective and less effective secondary school teachers on factor (Commitment to Basic Human Values) dimension of professional commitment, the results show that there is a significant difference between the two groups. The effective secondary school teachers focus on the truthiness, honesty and goodness of the students. They always try to develop the above qualities in their students. They play role model for their students. They develop the sense of truthfulness and honesty among the students. The effective secondary school teachers develop love, sympathy among the students. The less effective secondary school teachers are lacking these characteristics

\section{Conclusion:}

It has been found that there is a significant difference between the effective and less effective secondary school teachers on the teaching profession dimension of attitude towards teaching. Significant difference has been found between the effective and less effective secondary school teachers in the classroom teaching dimension of attitude towards teaching. There is a significant difference between the effective and less effective secondary school teachers on child centered practice dimension of attitude towards teaching. It has been revealed that there is a significant difference between the effective and less effective secondary school teachers in the educational process dimension of attitude towards teaching. 
IJAMSR 2 (1) www.ijamsr.com CrossRef: https://doi.org/10.31426/ijamsr.2019.2.1.1111

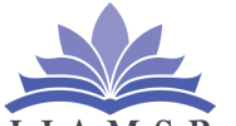

\section{Advanced Multidisciplinary}

International Journal of

I J A M S R

Scientific Research (

Significant difference has been found between
effective and less effective secondary school teachers on the pupil's dimension of attitude towards teaching. A significant difference has been established between the effective and less effective secondary school teachers on the teacher's dimension of attitude towards teaching. A significant difference has been established between the effective and less effective secondary school teachers on overall or a composite score of attitude towards teaching.

\section{References:}

1) Armstrong, M. (2006). A Handbook of Human resource Management Practice, Tenth Edition, Koran Page Publishing, London, , p. 264

2) Diuguid, Darraya.R. in( 2009). Studied Student Teachers Awareness, Preparedness and Attitudes of Issues Related to high Poverty Schools. . Journal of Experimental Education June 1955.

3) Christen, M., Ayer, G. and Sober man, D. (2006). Job Satisfaction, Job Performance, and Effort: A Reexamination Using Agency Theory, Journal of Marketing, January, Vol. 70, pp. 137-15

4) Davis, K. and Nostrum, J.W. (1985). Human Behavior at work: Organizational Behavior, 7 editions, McGraw Hill, New York, p.109

5) Herzberg, H. F. (1976). Motivation-Hygiene Profiles, p. 20 George, J.M. and Jones, G.R. (2008). Understanding and Managing Organizational behavior, Fifth Edition, Pearson/Prentice Hall, New Yersey, p. 78

6) Hop pock, R. (1935). Job Satisfaction, Harper and Brothers, New York, p. 47

7) Kaminski, B.S. (2007). Encyclopedia of Business and Finance, Second edition, Thompson Gale, Detroit, p. 446

8) Lawler, E.E. III and Porter, L.W. (1967). The Effect of Performance on Job Satisfaction, Industrial Relations, pp. 20-28

9) Locke, E.A. and Latham, G.P. (1990). A theory of goal setting and task performance, Prentice Hall, p.4 Lufthansa, F. (1998). Organizational Behavior, 8 Editions, McGraw-Hill/Irwin, Boston, p. 147

10) Mullins, J.L. (2005). Management and organizational behavior, Seventh Edition, Pearson Education Limited, Essex, p. 700
11) Mrunalini, T. \& Sankaraih.B. (2010). Study on Attitudes and Reflections of Prospective Teachers on Environmental Concerns. Social psychology of Education,6,61-90.

12) Panday, $R$ and Tripathy,(2006). Attitude towards teaching, Harper and Brothers, New York, p. 47

13) Rue, L.W. and Byers, L. (2003). Management, Skills and Application, 10 ed., McGraw-Hill/Irwin, New York, p. 259

14) Renu and Nanda (1999) ). A theory of goal setting and task performance, Prentice Hall, p.4

15) Specter, P.E. (1997). Job satisfaction: Application, assessment, causes and consequences, Thousand Oaks, Corsage Publications, Inc Stat, D. (2004). The Rutledge Dictionary of Business Management, Third edition, Rutledge Publishing, Detroit, p. 78

16) Sweeney, P.D. and McFarlin, D.B. (2005). Organizational Behavior, Solutions for Management, McGraw-Hill/Irwin, New York. 57

17) Sunitha and Badola, ( 2010). Study on studied, IGNOU (B.ED.)Teacher Trainees Attitude towards Awareness of the Fundamental Rights of Secondary school Students rights of secondary school students. . Journal of Higher Education Policy Management, vol.21, no.2,pp. 203-214.

18) Selvaraj Gnanaguru, A \& Suresh Kumar,M, in( 2008). Study on under Achievement of B.Ed Students in Relation to their Home Environment and Attitude towards Teaching. . Journal of Higher Education Policy Management, vol.21, no.2,pp. 203 214.

19) UNESCO, (1998). World Declaration on Education for All. Adapted by the World conference on Education for All meeting Basic Learning Needs. Jomtin, Published by UNESCO. 